\title{
Ibero-American missions: Political and Religious dimensions
}

\section{Presentation}

\author{
Elisa Frühauf Garcia[1]
}

I n 1772, the Governor of Buenos Aires conveyed the Governor of Chile some news that was "worth knowing about". At the time, a Christian native who had been able to escape after having spent some years as a prisoner of the "infidels" natives of Chile informed about a Jesuit who had just become a cacique. The prisoner had not mentioned the name of the Jesuit, but stated that the Jesuit had eight wives. He had every habit of "those barbarians", though well respected and known. ${ }^{1}$ Was the information given by the Christian native real? It is difficult to tell. Would colonial authorities have paid more attention to the news due to the anti-Jesuit conjuncture at the time? Maybe. However, the case indicates that a similar situation was considered to be likely in the colonial society. This reveals the aspects of the missionary experience which are not yet analyzed fully by historiography.

Till recently, studies on the missions had confirmed some presuppositions that were established about the subject. Interpretations were based on value judgment about the evangelizing activity, especially for Jesuits. These had shown absolute indifference towards the natives, whose wishes were seen as irrelevant in the installation of the Colonial society. Besides, little attention was given to the specific needs of the local people and the consequent readjustments that were required, during the negotiations that characterized the establishment of the Colonial society. ${ }^{2}$

Even though the border dimension of the missionary activity was emphasized by Herbert Eugene Bolton in an inspired essay published in 1917, it was rarely mentioned by many authors. Their approaches usually were isolated and 
shallow, which dwelt on a broader context. ${ }^{3}$ However, due to its border line condition, being at times real pioneers of territorial expansion, the missions were inseparable from the construction of the Iberian Empires. They could be seen as the "support for Colonial domain", as well-defined by Charles Boxer. ${ }^{4}$

Therefore, far from having a strictly spiritual dimension, the missions were essential for the process of institutionalizing the State in American domains. The work of the missionaries should turn natives into loyal vassals of the Monarchies, thus ensuring territorial occupation. It was also expected that new vassals should play a strategic military role in Iberian Empires: by defending their boundaries against the expansionist intentions of European rivals or the attacks of those natives who were hostile to the Colonial presence. The missions were as committed as they could be in relation to evangelization, but the Iberian Monarchs made geopolitical considerations in order to finance the missions: they were more generous when European competition was present. ${ }^{5}$

Far from having a strictly spiritual dimension,
the missions were essential for the process of
institutionalizing the State in American domains

The association between the Cross and the sword, however, show a series of outcomes in the studies about the missions. One of them, which is still a matter of discussion, is the relationship of the missionaries with their respective patronages and/or the States of their origin. Many Jesuits, for instance, were skilled politicians committed to the establishment of Colonial Empires. In the case of Portugal, Antônio Vieira was so involved in monarchy matters that he was correctly called the "king's Jesuit" by Ronaldo Vainfas. ${ }^{6}$ Facing imperial disputes, however, not all of them showed the same loyalty. Vainfas himself explains the trajectory of Manoel de Morais, a Jesuit who was born in São Paulo and crossed political and religious boundaries while the Dutch were present in the Northeast of Brazil. ${ }^{7}$

The involvement of Jesuits in several questionable events that took place in America, were they temporal or spiritual, were analyzed in three articles

\footnotetext{
${ }^{3}$ Herbert Eugene Bolton, "La misión como institución de la frontera en el septentrión de Nueva España” [1917], Estudios (Nuevos y Viejos) sobre la frontera, Anexo 4, Revista de Indias, Madri, 1990, CSIC, p. 45-60; David Sweet, "The Ibero-American Frontier Mission in Native American History", In: Erick Langer; Robert Jackson, The New Latin American Mission History, Lincoln, University of Nebraska Press, 1995; Salvador Bernabéu, "La invención del Gran Norte ignaciano: la historiografía sobre la Compañía de Jesús entre dos centenarios (19922006)", In: . (coord.), El Gran Norte Mexicano, Sevilla, CSIC, 2009.

${ }^{4}$ Charles Boxer, A Igreja e a Expansão Ibérica (1440-1770), Lisboa, Edições 70, 1989, p. 95.

${ }^{5}$ Herbert Eugene Bolton, "La misión como institución de la frontera en el septentrión de Nueva España" [1917], Estudios (Nuevos y Viejos) sobre la frontera, Anexo 4, Revista de Indias, Madri, 1990, CSIC, p. 45-60.

${ }^{6}$ Ronaldo Vainfas, Antônio Vieira: jesuíta do rei, São Paulo, Companhia das Letras, 2011. The relationship between Jesuits and the Portuguese empire was well described in: Dauril Alden, The Making of an Enterprise. The Society of Jesus in Portugal, Its Empire, and Beyond, 1540-1750, Stanford, Stanford University Press, 1996. ${ }^{7}$ Ronaldo Vainfas, Traição: um jesuíta a serviço do Brasil holandês processado pela Inquisição, São Paulo, Companhia das Letras, 2008.
} 
in this dossier. Lígio José de Oliveira Maia studies their participation in the war of Açu, one of the episodes in the process of territorial occupation in part of the Brazilian Northeast in the late $17^{\text {th }}$ and early $18^{\text {th }}$ centuries. In that context, alliances responded more to the urgent local issues in comparison to the determined principles pre-established by the religious orders or the intervention of the Crown.

The complex alliances and conflicts in which Jesuits were involved are also analyzed by Almir Diniz Carvalho Júnior, who emphasized on native populations. He focused his article on the conflicts between Antônio Vieira and the Principal $^{8}$ Lopo de Souza in Maranhão, in the 17th century. He demonstrates the limits and possibilities of actions conducted by Christian natives. Despite being put into the Colonial society in an unfavorable position, the natives were usually able to win the battles waged against important characters of Colonial history. He writes about the wit demonstrated by the natives in disputes, which was an essential element.

The setbacks of the work of missionaries are also analyzed in the article by Cristophe Giudicelli. In the Andean area of Tucumán, in the second half of the 17th century, the author demonstrates the transformation of kakán into the "enemy's language", though it ended up limited to the natives considered to be enemies of the Colonial society. Such incidents led to a dilemma for the Jesuits: after major investments were made to learn the language for evangelizing purposes, they ended up working as interpreters for the troops sent to fight the natives.

The articles in this dossier also explain the actions of the natives, which are now considered as vital to understand missionary activities. Research on different regions of America has demonstrated the active role of native populations. These articles reveal several concrete situations in which, to the detriment of imposing their points of view, the Jesuits acted as skilled negotiators. They made political and religious adjustments that were usually far from being conventional. ${ }^{9}$

At times, they did it for pleasure, as can be seen in the case of those who were too fond of the natives. This created embarrassing situations for the Society. The Jesuits did not publicize it, since their interest was to spread religion with their conversion skills. The native populations too had a considerable convincing ability, as it seemed to have happened in the aforementioned case of Chile.

After deep studies and dialogues with the natives' history, these analyses on the missionary experience question the several dimensions of the Catholic religion in its process to reorganize or create indigenous communities in America. Till recently, in Brazilian historiography, there was a fatalistic perception as far as the contact of natives with Catholicism. Especially due to the influence of the work by Luiz Felipe Baeta Neves, to whom the "village is no longer an

${ }^{8}$ The word represents a type of distinction of indigenous leaderships. t.n.

${ }^{9}$ About the reformulations in the missionary project of the Jesuits in Brazil, see: Charlotte de Castelnau-L'Estoile, Operários de uma vinha estéril: os jesuítas e a conversão dos índios no Brasil, 1580-1620. Bauru, Edusc, 2006. 
indigenous space. It is a space created by Christian culture". ${ }^{10}$ With such a perspective, the choices of the natives were limited. They could either escape from Colonial society by maintaining their "traditional religiosity", or convert into Catholicism. This can be viewed as an essential stage in their cultural annihilation caused by the Portuguese "Colonialism". The differences presented by historiography concerning the natives' history were essential to change this overview. As pointed out by James Lockhardt, "none of the categories, conversion or resistance, tells us all of the truth." ${ }^{11}$

Religion gained several meanings in the history of contacts: it could have been used by the Europeans of different beliefs as a convincing strategy, which ended up involving the natives in their religious and territorial disputes. ${ }^{12}$ It was also accepted by the natives themselves as the Spanish brought them many benefits to as a strategy to emphasize conversion. It was presented by the natives as a benefit that was brought in by the Spanish people, and with this strategy they emphasized conversion to the detriment of military conquest, in order to make their way into the colonial world, as demonstrated by Serge Gruzinski. ${ }^{13}$ [Generally, it is possible to infer that meanings of the villages were built and negotiated by the native population, as analyzed by Maria Regina Celestino de Almeida in the case of Rio de Janeiro. ${ }^{14}$ The opposite, however, also happened: in indigenous rebellions against the Colonial society, since Catholicism was suspected as a symbol of Iberian domination by the local people. ${ }^{15}$

\section{Till recently, in Brazilian historiography, there was a fatalistic perception as far as the contact of natives with Catholicism}

Therefore, when considering negotiation as an inseparable element from the missionary experience, studies demonstrate that the religiosity which was present in these regions represented more than a mere imposition of Catholicism: it was necessarily connected to the perceptions and

\footnotetext{
${ }^{10}$ Luiz Felipe Baeta Neves, O combate dos soldados de Cristo na terra dos papagaios, Rio de Janeiro, Forense Universitária, 1978, p. 117 (original emphasis).

"James Lockhardt, Los nahuas después de la conquista: historia social y cultural de los indios del México central, del siglo XVI al XVIII, México, Fondo de Cultura Económica, 1999, p. 291.

12James Axtell, The invasion within: the contest of cultures in Colonial North America, New York, Oxford University Press, 1985; Mark Meuwese, Brothers in arms, partners in trade: Dutch-indigenous alliances in the Atlantic world, 1595-1674, Leiden; Boston, Brill, 2012.

${ }^{13 S}$ erge Gruzinski, A colonização do imaginário: sociedades indígenas e ocidentalização no México espanhol. Séculos XVI-XVIII, São Paulo, Companhia das Letras, 2003.

${ }^{14}$ Maria Regina Celestino de Almeida, Metamorfoses indígenas: identidade e cultura nas aldeias coloniais do Rio de Janeiro, Rio de Janeiro, Arquivo Nacional, 2003.

${ }^{15}$ Steve Stern, Los pueblos indígenas del Perú y el desafío de la conquista española-Huamanga hasta 1640, Madri, Alianza, 1986; Ronaldo Vainfas, $A$ heresia dos índios: catolicismo e rebeldia no Brasil colonial, São Paulo, Companhia das Letras, 1995.
} 
wishes of the natives. ${ }^{16}$ This aspect was analyzed in the dossier by Charlotte de Castelnau-L'estoile. From the dialogues with the native leaderships and Capuchins involved in the experience of Equinoctial France in the early 17th century, the author demonstrates the negotiations that were present in interethnic contacts. By analyzing the sources produced by the missionaries, the author shows how these contacts were the result of dialogues that tried to conciliate, with varied rates of success, the several interests that moved the individuals in that historical context.

Many important studies resulted from the articulation of Catholicism with the establishment of the Colonial society, whose issues were essential to understand the relations of power inside the missionary spaces. The use of religion was an element of hierarchization and exclusion that had already been present in studies by Robert Ricard, which can be considered as classics in terms of evangelization, though the matter provides intriguing analyses and is still an open field for more research. ${ }^{17}$ After all, what was the role of religion in maintaining the natives subordinates to the Iberians in Colonial America?

It is clear that such a question does not have a single answer: situations change with time, as well as the regions and skills of the individuals involved in concrete situations. ${ }^{18}$ One of the essential themes is to relate the place of Catholicism and the missionary activity to the Colonial meanings of the term "native". The point of debates can be: how convenient was it to initiate natives into priesthood? The matter caused a lot of agitation in the Colonial society, especially in Mexico and Peru. ${ }^{19}$

However, it can be observed that the condition of neophytes excluded the natives from exercising several activities. As mentioned by some authors, including Juan Carlos Estenssoro, the conversion into Catholicism triggered

\footnotetext{
${ }^{16}$ Cristina Pompa, Religião como tradução: missionários, Tupi e Tapuia no Brasil colonial, Bauru, SP, Edusc, 2003; Paula Montero (org.), Deus na aldeia: missionários, índios e mediação cultural, São Paulo, Globo, 2006; Cynthia Radding, Paisajes de poder e identidad: fronteras imperiales en el desierto de Sonora y bosques de la Amazonía, Sucre, Fundación Cultural del Banco Central de Bolivia; Archivo y Biblioteca Nacionales de Bolivia, 2005. ${ }^{17 R o b e r t ~ R i c a r d, ~ L a ~ c o n q u i s t a ~ e s p i r i t u a l ~ d e ~ M e ́ x i c o, ~ M e ́ x i c o, ~ F o n d o ~ d e ~ C u l t u r a ~ E c o n o ́ m i c a, ~} 1986$ [1947]. The subject was also described by Charles Boxer, A Igreja e a Expansão Ibérica (1440-1770), Lisboa, Edições 70, 1989. ${ }^{18}$ For the relationship between the indigenous condition and the construction of a society in the Old Regime in colonial America, see: Karen Spalding, "¿Quiénes son los indios?", In: _. . De indio a campesino, Lima, Instituto de Estudios Peruanos, 1974, p. 147-193; Jacques Poloni-Simard, "Historia de los indios en los Andes, los indígenas en la historiografía andina: análisis y propuestas", Mundo Nuevo Nuevos Mundos, revista eletrônica, Paris, 2011. Disponível em: <www.nuevomundo.revues.org/651.htm>. Acesso em: 16 de junho de 2012. ${ }_{19}^{19}$ Robert Ricard, La conquista espiritual de México, México, Fondo de Cultura Económica, 1986 [1947], Ignacio Osorio Romero, La enseñanza del latín a los indios, México, D.F., Universidad Nacional Autónoma de México, 1990; Margarita Menegus Bornemann; Rodolfo Aguirre, Los indios, el sacerdocio y la Universidad en Nueva España, siglos XVI-XVIII, México, Universidad Nacional Autónoma de México, 2006; Monique AlaperrineBouyer, La educación de las elites indígenas en el Perú colonial, Lima, Instituto Francés de Estudios Peruanos; Instituto Riva-Agüero; Instituto de Estudios Peruanos, 2007; Pilar Gonzalbo Aizpuru, Historia de la educación en la época colonial: el mundo indígena. México, El Colegio de México, Centro de Estudios Históricos, 2000.
} 
a situation in which the natives were lacking autonomy in the religious field. They had to depend on the European priests, to meet their spiritual needs. ${ }^{20}$

The matter, as aforementioned, however, is filled with differences. In many cases, the control of the priests and missionaries over the indigenous communities was considerably restricted (for many reasons: they could not speak the local language, they were not interested, and there were only few people, among others). ${ }^{21}$

The article by Elisa Frühauf Garcia looks into the matter of the statute of the natives in the Colonial society from the case of the missions from Paraguay in the $18^{\text {th }}$ century. More than showing how this statute functioned, the author aims to demonstrate how the natives themselves realized their different juridictional condition, especially when it happened to be an obstacle in the way of their personal fulfillment of expectations.

Therefore, this dossier is aimed to gather articles of researchers who dedicated their analyses in the matter of the missions. Though some of the variables already brought up by some authors, as aforementioned, they were pushed into the background by historiography at a given time. However, the guest authors explain in detail, the disputes involving missionary spaces, the uncertainties that were characteristic of frontier regions, the lack of operationality of dichotomous variables and the impossibility in separating the religious contacts and the establishment of Colonial power. Enjoy your reading!

\footnotetext{
${ }^{20}$ Juan Carlos Estenssoro, Del paganismo a la santidad: la incorporación de los indios del Perú al catolicismo, 1532-1750, Lima, Instituto Francés de Estudios Andinos, 2003. Such overview began to change during the Iberian reforms of the second half of the 18th century, when promises of juridical equality to the natives included the incentive to the exercise of priesthood, including for the natives in border regions. About the theme, see: David Weber, Bárbaros: los españoles y sus salvajes en la era de la llustración, Barcelona, Crítica, 2007, specially chapter 3, "La ciencia de criar hombres", p. 139-205.

${ }^{21}$ About the theme, see, for instance, James Lockhardt, Los nahuas después de la conquista: historia social y cultural de los indios del México central, del siglo XVI al XVIII, México, Fondo de Cultura Económica, 1999.
} 